\title{
Chapter 8 \\ Pore Water Geochemistry as a Tool for Identifying and Dating Recent Mass-Transport Deposits
}

\author{
Susann Henkel, Tilmann Schwenk, Till J.J. Hanebuth, Michael Strasser, \\ Natascha Riedinger, Michael Formolo, Juan Tomasini, Sebastian Krastel, \\ and Sabine Kasten
}

\begin{abstract}
Several previous studies have shown that submarine mass-movements can profoundly impact the shape of pore water profiles. Therefore, pore water geochemistry and diffusion models were proposed as tools for identifying and dating recent (max. several thousands of years old) mass-transport deposits (MTDs). In particular, sulfate $\left(\mathrm{SO}_{4}{ }^{2-}\right.$ ) profiles evidentially indicate transient pore water conditions generated by submarine landslides. After mass-movements that
\end{abstract}

S. Henkel $(\bowtie) \cdot$ S. Kasten

Institute of Geology and Mineralogy, University of Cologne, Zülpicher Str. 49a, 50674 Cologne, Germany

e-mail: susann.henkel@uni-koeln.de

T. Schwenk

Center for Marine Environmental Sciences (MARUM), Faculty of Geosciences,

University of Bremen, Klagenfurter Str, 28359 Bremen, Germany

T.J.J. Hanebuth

Center for Marine Environmental Sciences (MARUM), Faculty of Geosciences,

University of Bremen, Leobener Str, 28359 Bremen, Germany

M. Strasser

Geological Institute, ETH Zurich, Sonneggstrasse 5, 8092, Zürich, Switzerland

MARUM - Centre for Marine Environmental Sciences, University of Bremen, Bremen, Germany

N. Riedinger

University of California, 900 University Avenue, Riverside, CA 92521, USA

M. Formolo

The University of Tulsa, 800 South Tucker Drive, Tulsa, OK 74104, USA

J. Tomasini

Administración Nacional de Combustibles Alcohol y Pórtland (ANCAP),

Paysandú s/n esq. Avenida del Libertador, Montevideo 11100, Uruguay

S. Krastel

Leibniz Institute of Marine Sciences (IFM-GEOMAR), Wischhofstr. 1-3,

24148 Kiel, Germany 
result in the deposition of sediment packages with distinct pore water signatures, the $\mathrm{SO}_{4}{ }^{2-}$ profiles can be kink-shaped and evolve into the concave and linear shape with time due to molecular diffusion. Here we present data from the RV METEOR cruise M78/3 along the continental margin off Uruguay and Argentina. $\mathrm{SO}_{4}{ }^{2-}$ profiles of 15 gravity cores are compared with the respective acoustic facies recorded by a sediment echosounder system. Our results show that in this very dynamic depositional setting, non-steady state profiles occur often, but are not exclusively associated with mass-movements. Three sites that show acoustic indications for recent MTDs are presented in detail. Where recent MTDs are identified, a geochemical transport/reaction model is used to estimate the time that has elapsed since the perturbation of the pore water system and, thus, the timing of the MTD emplacement. We conclude that geochemical analyses are a powerful complementary tool in the identification of recent MTDs and provide a simple and accurate way of dating such deposits.

Keywords Mass-movement $\bullet$ Pore water profiles - Non-steady state - Seismoacoustic facies $\bullet$ Geochemical modeling

\subsection{Introduction}

Seismo-acoustic approaches provide the means to estimate dimensions of MTDs, but for absolute dating and identifying small-scale internal structures they need to be complemented by sediment data. However, based on visual core descriptions, MTDs are often hard to distinguish from homogeneous hemipelagic sediments, as both might lack clear stratification. Pore water profiles can be used to close this gap as was demonstrated first by De Lange (1983), who identified a "fresh-to-brackish sediment 'slab', with preservation of structural and pore water composition" underlying marine sediments in the Norwegian Sea.

With respect to pore water, sediments are classified into steady state and nonsteady state systems (Schulz 2006). Simplified, steady state systems are in equilibrium and show a linear $\mathrm{SO}_{4}{ }^{2-}$ decrease with depth towards the sulfate-methane transition zone (SMTZ) where the process of anaerobic oxidation of methane (AOM; e.g., Barnes and Goldberg 1976) occurs. Zabel and Schulz (2001) and Hensen et al. (2003) presented non-steady state $\mathrm{SO}_{4}{ }^{2-}$ profiles from the Zaire deep-sea fan and the continental margin off Uruguay and suggested that kink, concave-up, and s-type $\mathrm{SO}_{4}^{2-}$ profiles can be explained by submarine landslides that carry their initial pore water signals downslope. The base of an MTD can, according to the authors, be indicated by a kink of the pore water profile, which evolves into a concave and finally a linear shape due to molecular diffusion. The re-equilibration of the $\mathrm{SO}_{4}{ }^{2-}$ pore water profile was modeled to estimate the timing of the mass-movement.

With this review paper, we expand on the previous approaches and give a regional compilation showing the pervasiveness of non-steady state $\mathrm{SO}_{4}{ }^{2-}$ profiles at the continental margin off Uruguay and Argentina and their relation to MTDs as indicated 


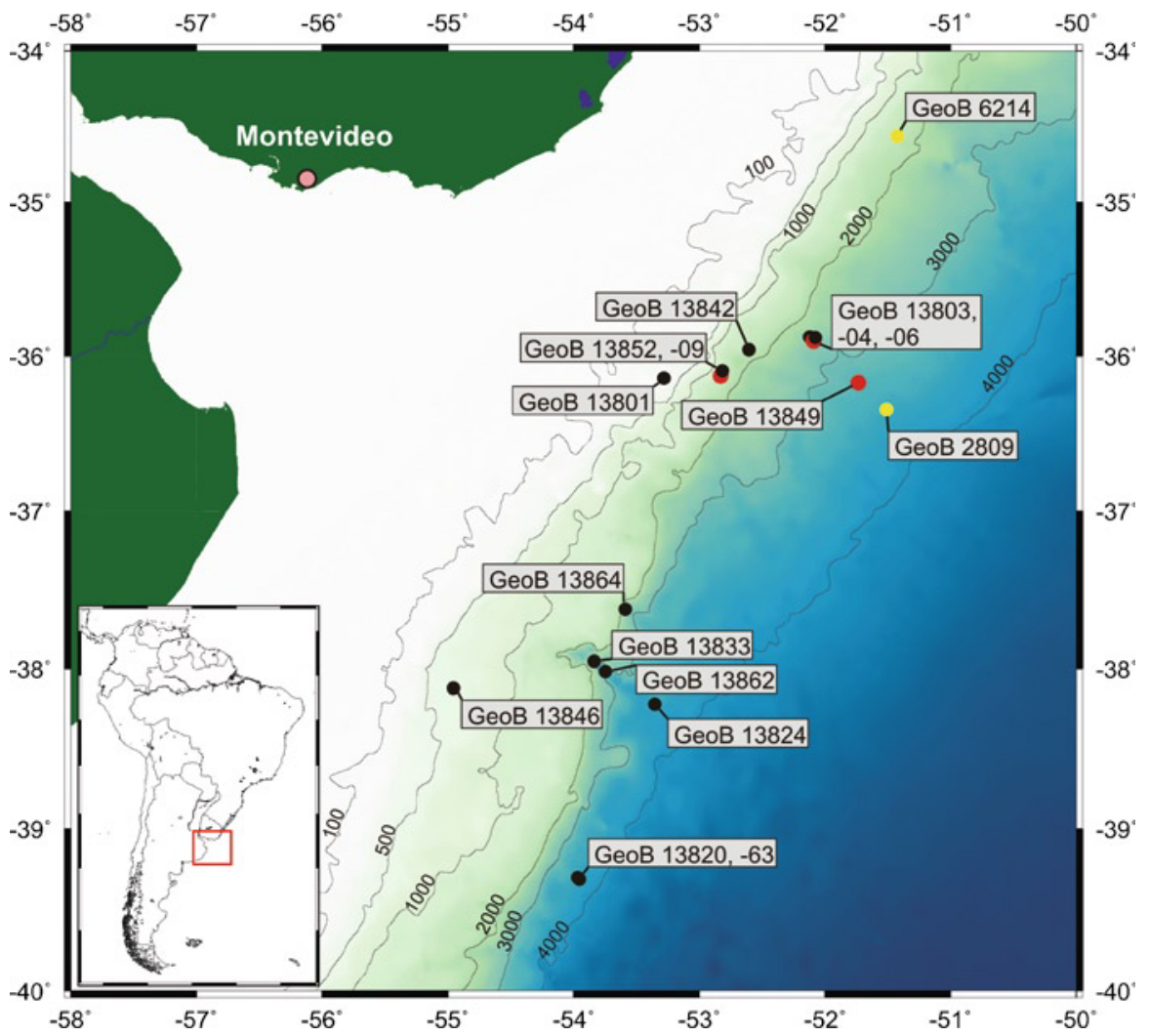

Fig. 8.1 Study area off Uruguay and Argentina and core locations. The sites marked in red are discussed in this study. The yellow dots mark the sites that are discussed in detail by Hensen et al. (2003)

by sediment echosounder data. The integration of geochemical, sedimentological, and geophysical data allows a better understanding of the dynamic interactions of pore water, sediments, and physical processes and offers a unique approach to date recent MTDs.

\subsection{Study Area}

The study area (Fig. 8.1) is characterized by dynamic oceanographic conditions including the Brazil-Malvinas Confluence near $38^{\circ} \mathrm{S}$ and the interaction of Antarctic water masses with the North Atlantic Deep Water at different depths (Piola and Matano 2001). The sedimentary processes along the margin were described in detail by Krastel et al. (2011). Mass movements occur within canyons and on the lower slope (Krastel et al. 2011). 


\subsection{Material and Methods}

Sediment echosounder data were obtained with the Atlas Hydrographic PARASOUND system, which gives a dm-scale vertical resolution and a horizontal resolution of $7 \%$ of the water depth. Gravity cores were retrieved from various water depths (Table 8.1). Methane $\left(\mathrm{CH}_{4}\right)$ and pore water samples were gained as described in Henkel et al. (2011).

We performed transport/reaction modeling using the software CoTReM (Adler et al. 2001) and following the method of Hensen et al. (2003). We consider AOM (Eq. 8.1) as the most important process for $\mathrm{SO}_{4}{ }^{2-}$ reduction at depth.

$$
\mathrm{CH}_{4}+\mathrm{SO}_{4}{ }^{2-} \rightarrow \mathrm{HCO}_{3}^{-}+\mathrm{HS}^{-}+\mathrm{H}_{2} \mathrm{O}
$$

Borowski et al. (1996) proposed that the upward flux of $\mathrm{CH}_{4}$ can be quantitatively estimated from the downward flux of $\mathrm{SO}_{4}{ }^{2-}$. Measured $\mathrm{CH}_{4}$ data were not used for the simulation because of the known inaccuracy related to degassing during core retrieval (e.g., Dickens et al. 1997). Except for bioirrigation and sedimentation rate (SR) that are considered in the model as advective terms, we simulated exclusively diffusive transport of pore water species. The reaction-specific change in concentration at a specific sediment depth $\left(\Delta C_{\mathrm{s}, \mathrm{d}}\right)$ was calculated as follows:

$$
\Delta C_{\mathrm{s}, \mathrm{d}}=R_{\mathrm{s}, \mathrm{d}} \times d t_{\mathrm{num}} \times S C_{\mathrm{s}, \mathrm{d}}
$$

Where $R_{\mathrm{s}, \mathrm{d}}$ is the reaction rate, $\mathrm{dt}_{\mathrm{num}}$ is the time step used in the model run, and $S C_{\mathrm{s}, \mathrm{d}}$ is a stoichiometric factor (see Hensen et al. 2003). Details to $R_{\mathrm{s}, \mathrm{d}}$ are given in Sect. 8.4.

\subsection{Results and Discussion}

Identification of submarine landslides by $\mathrm{SO}_{4}{ }^{2-}$ profiles is restricted to MTDs that are only a few meters thick. A thicker MTD that is not completely penetrated by the gravity corer may show a linear $\mathrm{SO}_{4}^{2-}$ profile in the cored interval. In such a case, the change in gradient (the kink) occurs below the cored depth and the MTD could thus not be identified on the basis of the $\mathrm{SO}_{4}{ }^{2-}$ profile. Fifteen of the investigated cores penetrated the SMTZ and therefore provided the required information for an appropriate description of the $\mathrm{SO}_{4}{ }^{2-}$ profile (Table 8.1, Fig. 8.1). The $\mathrm{SO}_{4}{ }^{2-}$ profiles are classified into the types linear, concave-up, and kink shape (Table 8.1). The acoustic facies with special emphasis on reflection configuration and amplitude are included as well in Table 8.1. Nine of the investigated cores reveal non-linear profiles. Three of these nine cores (GeoB 13801, -03, -42) are not related to MTDs as indicated by PARASOUND data (Table 8.1). We therefore consider that the non-linearity of these $\mathrm{SO}_{4}{ }^{2-}$ profiles can be attributed to alternative processes, such as $\mathrm{CH}_{4}$ gas ebullition (Haeckel et al. 2007) or a sudden increase in the upward flux of $\mathrm{CH}_{4}$ (Kasten et al. 2003) possibly due to gas hydrate dissociation. 


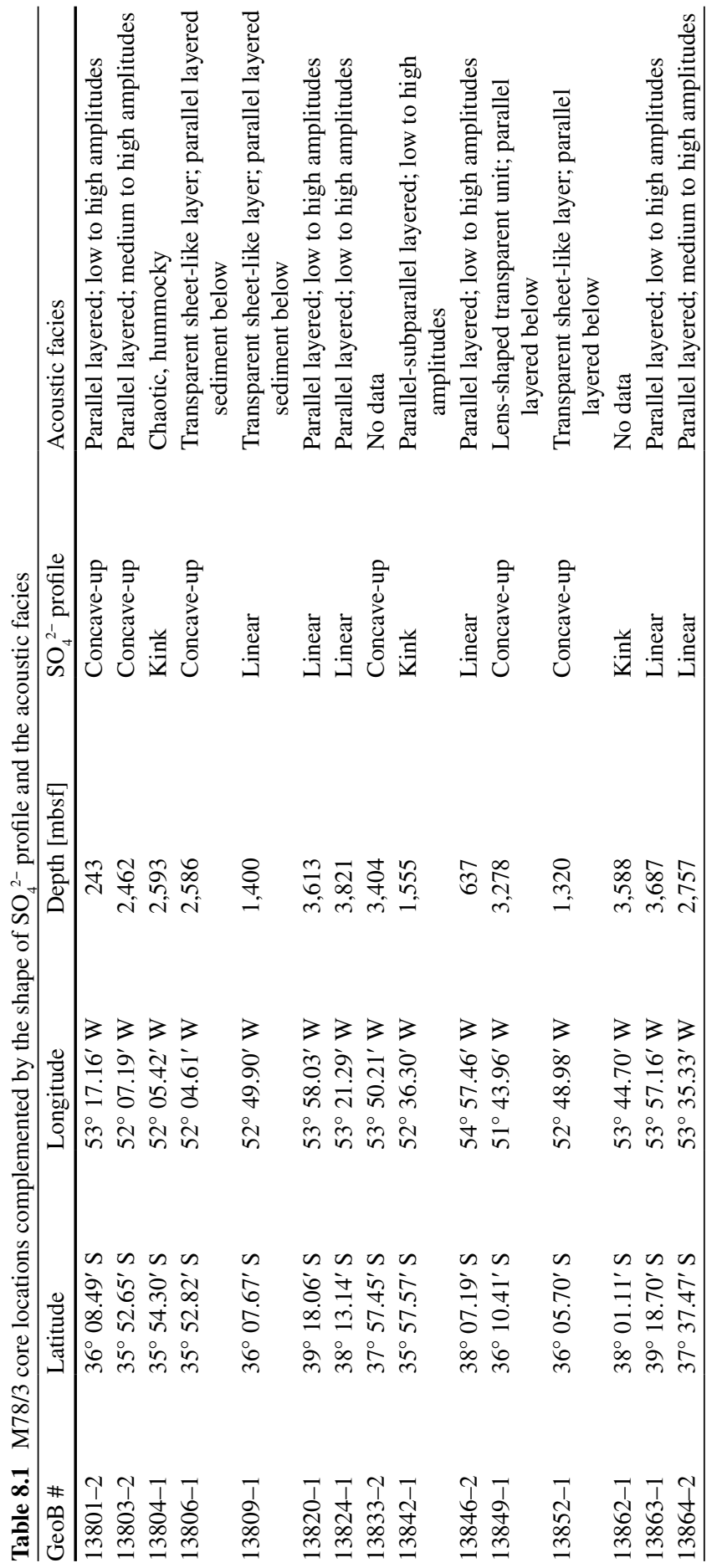




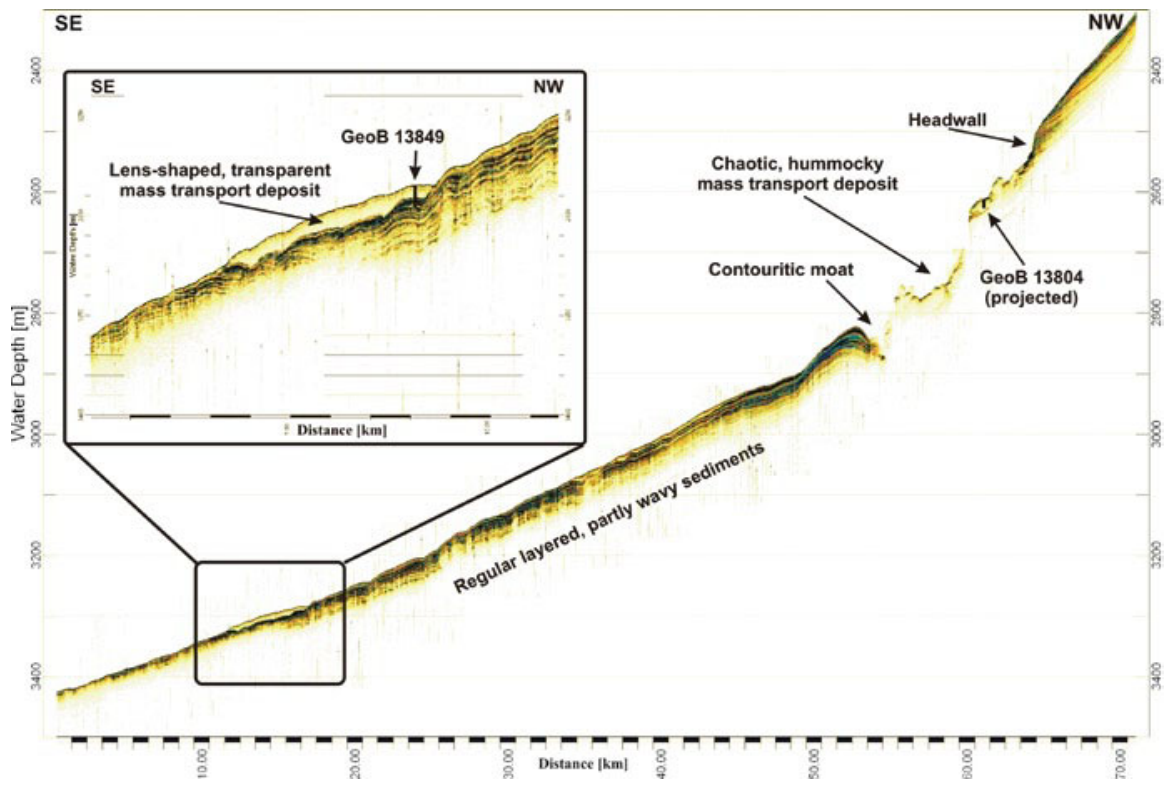

Fig. 8.2 PARASOUND profile obtained during RV METEOR cruise M78/3 crossing the continental slope in SE-NW direction. The profile shows the position of core GeoB 13804 (projected) at a hummocky surface interpreted as mass-transport deposit. Site GeoB 13849 is shown in the close-up at the rim of a lens-shaped transparent unit overlying parallel layered sediments. At the core location, the transparent unit interpreted as a gravity flow deposit is $\sim 6 \mathrm{~m}$ thick

At several sites (GeoB 13806, $-09,-49,-52)$, acoustically transparent deposits overlay parallel layered sediments (Table 8.1, Figs. 8.2 and 8.3). In general, such transparent units represent either homogeneous or extremely heterogeneous sediments with loss of internal bedding (Kuehl et al. 2005). Transparent acoustic facies often represent MTDs, which may also show a hummocky surface and an erosional base (Hampton et al. 1996).

Three sites (GeoB 13804, -49, and -09) will be discussed, that represent the three different categories of $\mathrm{SO}_{4}{ }^{2-}$ profiles and which have all been recovered from sites that show acoustic indication of potential MTDs (Fig. 8.4). Core GeoB 13804 was retrieved from an acoustically chaotic facies with a hummocky surface. Core GeoB 13849 was recovered from a lens-shaped transparent unit (Fig. 8.2) and core GeoB 13809 was taken from an acoustically-transparent, sheet-like deposit downslope of a prominent scar (Krastel et al. 2011). This 5-6 m thick sedimentary body is characterized by parallel upper and lower boundaries and shows no termination within the surveyed area (Fig. 8.3). The interpretation of this feature from PARASOUND data is therefore not unambiguous. It may result either from downslope sediment-transport processes or from sheeted-contouritic deposition of homogeneous material (see discussion below). 


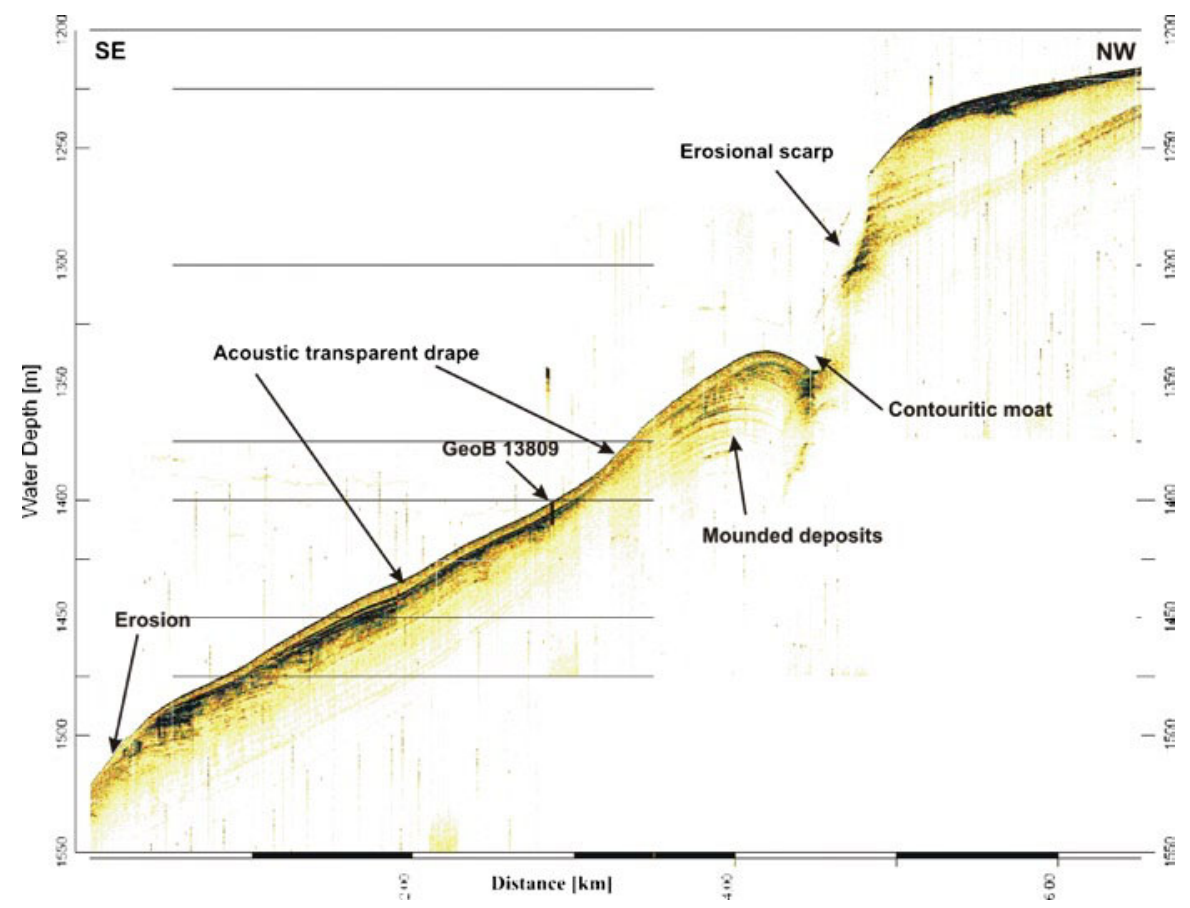

Fig. 8.3 PARASOUND profile obtained during RV METEOR cruise M78/3 crossing the continental slope in SE-NW direction. Station GeoB 13809 is located to the SE of a contouritic moat. The profile at the core location shows parallel layered sediments and a strong reflector in 5-6 depth that has an erosive character and is overlain by a sheet-like transparent unit

\subsubsection{Pore Water Profiles at Potential MTD Sites}

The $\mathrm{SO}_{4}{ }^{2-}$ profile at site $\mathrm{GeoB} 13804$ has a kink shape with a gradient change at $\sim 2.8 \mathrm{~m}$ (Fig. 8.4). A sedimentological boundary between gray and very dark gray mud occurs at $2.43 \mathrm{~m}$, thus $\sim 0.35 \mathrm{~m}$ above the gradient change of the $\mathrm{SO}_{4}{ }^{2-}$ profile (Fig. 8.4). Above this sedimentological contact, which is also reflected by a significant downcore increase in undrained shear strength (Henkel et al. 2011), the core shows a stack of undisturbed sand/silt layers (Fig. 8.4). Bioturbation structures are present between 0 and $2.79 \mathrm{~m}$ depth. Bioirrigation and vertical gas or fluid migration in the whole $\sim 2.8 \mathrm{~m}$ thick package can be excluded (Henkel et al. 2011). Therefore, we conclude that the kink shaped $\mathrm{SO}_{4}{ }^{2-}$ profile is the result of the combination of bioirrigation to a paleo-depth of $0.35 \mathrm{~m}$ and a $\sim 2.4 \mathrm{~m}$ thick slide mass. In accordance with the studies of Zabel and Schulz (2001) and Hensen et al. (2003) at other locations, the most recent mass-transport event at site GeoB 13804 must have happened in the form of a coherent slide mass carrying its initial $\mathrm{SO}_{4}{ }^{2-}$ profile downward, because the internal structure of this package was not destroyed. It is known from previous expeditions that sites with nearly constant $\mathrm{SO}_{4}{ }^{2-}$ concentrations over the length of a 
S. Henkel et al.

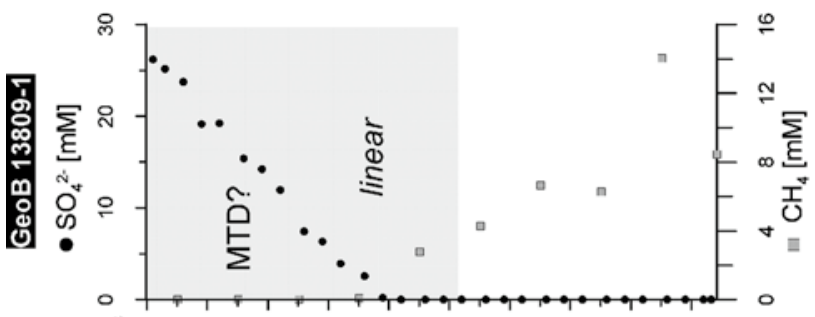

चี ज

巳

웧

要过

홍

능

욤

品 导

๑ै 훙

过苛

可:

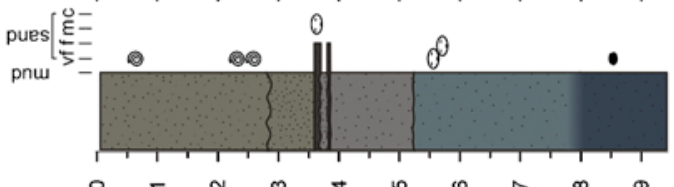

ปे ठิ

on

乎

(

\&ै

क

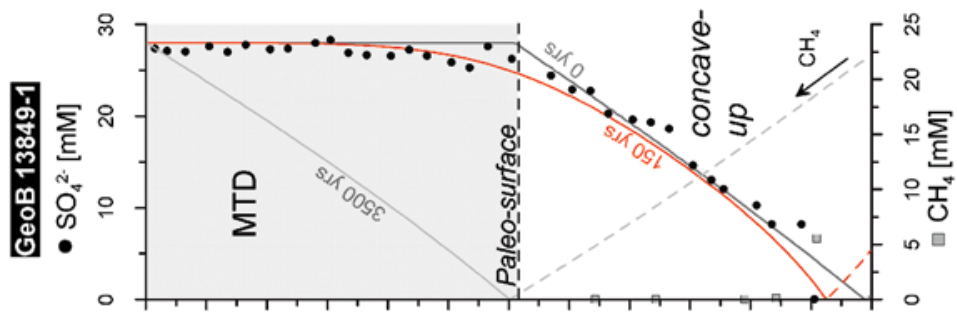

क क क

읭요

든

i.

잉

光

का

承

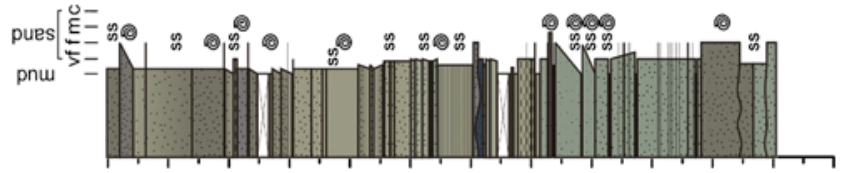

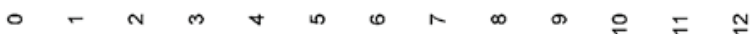

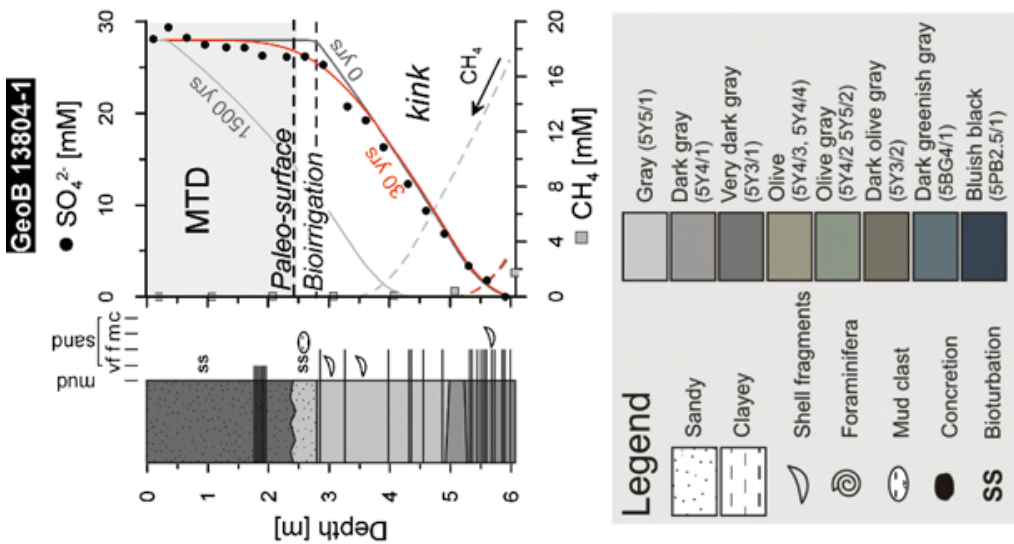

के

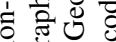

का $\cong$

$\stackrel{2}{ \pm} \cdot \frac{0}{\circ}$

$\dot{0} . \Xi 0$

$\therefore$ 过

ठั่

$\lambda \dot{\overline{0}}$

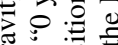

要

का

\& 훙 훙

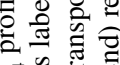
\& U: छे छ के के 0 i. 요용

$\therefore \dot{0} . \Xi$

ชิ응 छ ㄴํㅇ हे है 
Table 8.2 Parameterization for transport and reaction modeling for sites GeoB 13804 and -49

\begin{tabular}{llll}
\hline Basic parameters GeoB & $13804 /-49$ & \multicolumn{3}{l}{ Boundary conditions GeoB 13804/-49 } \\
\hline Model length [m] & $8 / 15$ & Sedimentation rate $\left[\mathrm{cm} \mathrm{kyear}{ }^{-1}\right]$ & $80-180^{\mathrm{a} /} / 5^{\mathrm{b}}$ \\
Cell discretisation $[\mathrm{cm}]$ & 5 & Upper boundary $\mathrm{SO}_{4}^{2-}\left[\mathrm{mmol} \mathrm{l}^{-1}\right]$ & $28^{\mathrm{c}}$ \\
Time step [year] & 0.05 & Upper boundary $\mathrm{CH}_{4}\left[\mathrm{mmol} \mathrm{l}^{-1}\right]$ & $0^{\mathrm{c}}$ \\
Porosity $\varphi$ & $0.6 / 0.7^{\mathrm{d}}$ & Lower boundary $\mathrm{SO}_{4}^{2-}\left[\mathrm{mmol} \mathrm{l}^{-1}\right]$ & 0 \\
Temperature $\left[{ }^{\circ} \mathrm{C}\right]$ & 3.5 & Lower boundary $\mathrm{CH}_{4}\left[\mathrm{mmol} \mathrm{l}^{-1}\right]$ & $40 / 35$ \\
\hline Diffusion coefficients & $\mathrm{D}_{0}$ & $\mathrm{D}_{\text {sed }}$ & \\
\hline $\mathrm{SO}_{4}{ }^{2-}\left[\mathrm{cm}^{2}\right.$ year $\left.^{-1}\right]$ & 179.5 & 88.79 & \\
$\mathrm{CH}_{4}\left[\mathrm{~cm}^{2}\right.$ year & & \\
\hline
\end{tabular}

${ }^{a}$ Exceptionally high sedimentation rate derives from unsupported ${ }^{210} \mathrm{~Pb}$. For details see Henkel et al. (2011)

${ }^{\mathrm{b}}$ According to Ewing et al. (1971) and Hensen et al. (2003)

'Bottom water concentrations

${ }^{\mathrm{d} A v e r a g e ~ p o r o s i t y ~ a s ~ m e a s u r e d ~ o n ~ b o a r d ~}$

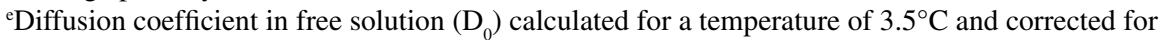
tortuosity $(\theta)$ after Boudreau (1997); $\mathrm{D}_{\text {sed }}=\mathrm{D}_{0} / \theta^{2}$, while $\theta^{2}=1-\ln \left(\varphi^{2}\right)$

gravity core (as it is expected for the source area of the slide) occur in the study area (Bleil et al. 1994).

Site GeoB 13849 is characterized by a concave-up shaped $\mathrm{SO}_{4}^{2-}$ profile (Fig. 8.4). Based on PARASOUND data, the thickness of the surficial MTD unit is estimated to be $\sim 6 \mathrm{~m}$ (Fig. 8.2), which fits well to the $\mathrm{SO}_{4}^{2-}$ profile showing a change in gradient at the same depth. The lithology displays a sharp contact between bluish black fine sand interbedded with olive muddy fine sand below and dark gray muddy fine sand above $6.10 \mathrm{~m}$. Based on the geochemical and PARASOUND data this boundary is interpreted as the base of the MTD.

The visual description of core GeoB 13809 reveals a sharp, irregular contact at $5.12 \mathrm{~m}$. Since this boundary correlates to the base of the acoustically transparent layer imaged in PARASOUND data, it possibly represents the base of an MTD (Fig. 8.4). Core GeoB 13809 displays a linear $\mathrm{SO}_{4}{ }^{2-}$ profile. The inferred massmovement thus took place several hundreds to thousands of years ago, so that the $\mathrm{SO}_{4}^{2-}$ profile could diffusively re-equilibrate into a linear shape.

\subsubsection{Geochemical Transport/Reaction Modeling}

The diffusive re-equilibration of the $\mathrm{SO}_{4}{ }^{2-}$ profile over time was simulated for sites GeoB 13804 and -49 (parameterization in Table 8.2). A maximum reaction rate $R_{\mathrm{s}, \mathrm{d}}$ of $0.1 \mathrm{~mol} \mathrm{dm}^{-3}$ year $^{-1}$ was defined to produce a broad SMTZ with overlapping $\mathrm{CH}_{4}$ and $\mathrm{SO}_{4}{ }^{2-}$ profiles at site $\mathrm{GeoB} 13804$ (Fig. 8.4). That rate was used as long as the reactants were available in sufficient amounts (0th order kinetics). For lower concentrations of the reactants and for site GeoB 13849, where the SMTZ is restricted to a distinct depth, the AOM reaction rate was determined based on second order kinetics. The starting conditions for the model runs are shown as gray 
lines in Fig. 8.4: Each sediment package (the MTD and the sediment below) still hosts its initial pore water characteristic. For site GeoB 13804, the model results reveal that the proposed mass-movement took place less than 30 years ago (Fig. 8.4, Henkel et al. 2011). The event could therefore have been associated with a weak $\left(5.2 \mathrm{~m}_{\mathrm{b}}\right.$ ) earthquake in 1988 (Henkel et al. 2011). The epicenter was $\sim 70 \mathrm{~km}$ away from the core location (Assumpção 1998; Benavídez Sosa 1998).

According to the best fit between measured $\mathrm{SO}_{4}{ }^{2-}$ concentrations and the simulation (red line in Fig. 8.4), the MTD at site GeoB 13849 occurred approximately 150 years ago. The age of the MTD roughly corresponds to an earthquake in 1848 (intensity in Montevideo IV-V based on the Mercalli scale) with an epicenter $200 \mathrm{~km}$ west of the study site (Benavídez Sosa 1998). Complete re-equilibration of the $\mathrm{SO}_{4}{ }^{2-}$ profile is reached after $\sim 3,500$ years (Fig. 8.4).

\subsection{Conclusions}

This study demonstrates that integrating geophysical, sedimentological, and pore water data provides a scientifically valid approach to constrain the ages of recent MTDs. Pore water geochemical analyses are cost-efficient, easily accessible compared to other methods, and can provide information regarding paleosurfaces or erosive contacts that are not apparent from visual core inspection. Applying a comprehensive, multi-disciplinary approach as presented in this study over a larger region could provide a historical record of the frequencies of mass-transport events. Such a record may be compared to documented earthquakes and in this way shed light on the dynamic and complex links between various geological processes.

Acknowledgments GL Arnold and $\mathrm{J}$ Sawicka are acknowledged for analyzing $\mathrm{SO}_{4}{ }_{4}^{2-}$. R Violante and $\mathrm{V}$ Bender are acknowledged for the visual description of the cores. The PARASOUND figures were created using the free software SENT developed by H Keil, University of Bremen. The manuscript benefited from the very constructive reviews of C Hensen and B Dugan. This study was funded by the Deutsche Forschungsgemeinschaft (DFG) in the frame of the International Graduate College "Proxies in Earth History" (EUROPROX) and the Research Center/Cluster of Excellence "The Ocean in the Earth System" (MARUM). We appreciate further financial support from the Helmholtz Association (AWI Bremerhaven). All data are available via the database Pangaea (http://www.pangaea.de).

\section{References}

Adler M, Hensen C, Wenzhöfer F, Pfeifer K, Schulz HD (2001) Modeling of calcite dissolution by oxic respiration in supralysoclinal deep-sea sediments. Mar Geol 177:167-189

Assumpção M (1998) Seismicity and stresses in the Brazilian passive margin. Bull Seismol Soc Am 88:160-169

Barnes RO, Goldberg ED (1976) Methane production and consumption in anoxic marine sediments. Geology 4:297-300

Benavídez Sosa A (1998) Sismicidad y sismotectónica en Uruguay. Física de la Tierra 10:167-186 
Bleil U and cruise participants (1994) Report and preliminary results of Meteor Cruise M29/2, Montevideo - Rio de Janeiro, 15.07.1994 - 08.08.1994. Berichte aus dem Fachbereich Geowissenschaften der Universität Bremen 59

Borowski WS, Paull CK, Ussler W (1996) Marine pore-water sulfate profiles indicate in situ methane flux from underlying gas hydrate. Geology 24:655-658

Boudreau BP (1997) Diagenetic models and their implementation: modeling transport and reactions in aquatic sediments. Springer, Berlin/Heidelberg/New York

De Lange GJ (1983) Geochemical evidence of a massive slide in the southern Norwegian Sea. Nature 305:420-422

Dickens GR, Paull CK, Wallace PJ (1997) Direct measurement of in situ methane quantities in a large gas-hydrate reservoir. Nature 385:426-428

Ewing M, Eittreim SL, Ewing JI, Le Pichon X (1971) Sediment transport and distribution in the Argentine basin. 3. Nepheloid layer and processes of sedimentation. Phys Chem Earth 8:49-77

Haeckel M, Boudreau BP, Wallmann K (2007) Bubble-induced porewater mixing: a 3-D model for deep porewater irrigation. Geochim Cosmochim Acta 71:5135-5154

Hampton MA, Lee HJ, Locat J (1996) Submarine landslides. Rev Geophys 34:33-59

Henkel S, Strasser M, Schwenk T, Hanebuth TJJ, Hüsener J, Arnold GL, Winkelmann D, Formolo M, Tomasini J, Krastel S, Kasten S (2011) An interdisciplinary investigation of a recent submarine mass transport deposit at the continental margin off Uruguay. Geochem Geophys Geosyst 12:Q08009. doi:10.1029/2011GC003669

Hensen C, Zabel M, Pfeifer K, Schwenk T, Kasten S, Riedinger N, Schulz HD, Boetius A (2003) Control of sulfate pore-water profiles by sedimentary events and the significance of anaerobic oxidation of methane for the burial of sulfur in marine sediments. Geochim Cosmochim Acta 67:2631-2647

Kasten S, Zabel M, Heuer V, Hensen C (2003) Processes and signals of nonsteady-state diagenesis in deep-sea sediments and their pore waters. In: Wefer G et al (eds) The south Atlantic in the late Quaternary: reconstruction of mass budget and current systems. Springer, Berlin/Heidelberg/ New York, pp 431-459

Krastel S, Wefer G, Hanebuth TJJ, Antobreh AA, Freudenthal T, Preu B, Schwenk T, Strasser M, Violante R, Winkelmann D, M78/3 shipboard scientific crew (2011) Sediment dynamics and geohazards off Uruguay and the de la Plata River region (Northern-Argentina and Uruguay). Geo-Mar Lett 31:271-283

Kuehl SA, Allison MA, Goodbred SL, Kudrass HR (2005) The Ganges-Brahmaputra delta. In: Giosan L, Bhattacharya JP (eds) River deltas — concepts, models, and examples, SEPM Special Publication No. 83, pp 413-434

Piola AR, Matano RP (2001) Brazil and Falklands (Malvinas) currents. In: John HS et al (eds) Encyclopedia of ocean sciences. Academic, Oxford, pp 422-430

Schulz HD (2006) Quantification of early diagenesis: dissolved constituents in pore water and signals in the solid phase. In: Schulz HD, Zabel M (eds) Marine geochemistry. Springer, Berlin, pp 73-124

Zabel M, Schulz HD (2001) Importance of submarine landslides for non-steady state conditions in pore water systems - lower Zaire (Congo) deep-sea fan. Mar Geol 176:87-99 